Jorunn Spord Borgen

Norges Idrettshøyskole og Høgskulen på Vestlandet

Bjørg Oddrun Hallås

Høgskulen på Vestlandet

Eli Heldaas Seland

Høgskulen på Vestlandet

Eli Kristin Aadland

Høgskulen på Vestlandet

Njål Vindenes

Høgskulen på Vestlandet

DOI: http://dx.doi.org/10.5617/adno.7901

\title{
De praktiske og estetiske fagene i skole og lærerutdanning - historisk konseptualisering
}

\begin{abstract}
Sammendrag
Artikkelen tar utgangspunkt i fagene kroppsøving, kunst- og håndverk, mat og helse og musikk i skole og lærerutdanning. Faggruppen benevnes ofte som praktiske og estetiske fag. Vi undersøker hvordan konseptualisering av faggruppen og fagene foregår historisk, og nøkkelhendelser som kan ha hatt betydning. Vi har søkt i skrevne kilder og benytter tjenesten NB N-gram fra Nasjonalbiblioteket, som gjør det mulig å søke etter forekomst av bestemte ord og ordfrekvenser, til å skaffe et historisk bilde av forekomsten av ulike begreper i styringsdokumenter. Vi har utviklet en tidslinje for å avgrense utdanningspolitiske hendelser som kan ha hatt betydning for hvordan fagene er konseptualisert. Individuelle intervju ga oss kunnskap om eksplisitte og mer implisitte og oversette nøkkelhendelser som kan ha hatt historisk betydning i de praktiske og estetiske fagene i skole og lærerutdanning. Resultatene viser at ulike konseptualiseringer kan ha sammenheng med stadig pågående diskusjoner angående de praktiske og estetiske fagene som faggruppe og fag, og samspillet dette til enhver tid inngår i. Studien bidrar med forskning som kan bli nyttig for fagutvikling i fremtidig utdanningsfelt. Det er behov for en videre diskusjon om faggruppen og enkeltfagenes egenart, og om operasjonaliseringer av fagene i skole og lærerutdanning.
\end{abstract}

Nøkkelord: praktiske og estetiske fag, konseptualisering, skole, lærerutdanning 


\title{
The practical and aesthetic subjects in school and teacher education - historical conceptualization
}

\begin{abstract}
The article discusses the conceptualization of practical and aesthetic subjects as knowledge field in school and teacher education. These subjects are physical education, arts and crafts, food and health and music. We investigate historical conceptualization and explicit as well as more implicit key moments that are typically overlooked and that may have been important to the development of the subject group in school and teacher education. We have searched in texts and used the service NB N-gram from the National Library, which makes it possible to search for occurrence of specific words and word frequencies, to obtain a historical picture of the occurrence of different concepts in steering documents. Further, we have developed a timeline to delineate educational policy events that may have influenced how the subjects and subject group are conceptualized. Individual interviews gave us knowledge of important professional and historical key moments for the subjects in school and teacher education. Different conceptualisations may be related to constantly ongoing discussions regarding the practical and aesthetic subjects as a subject group and individual subjects in school and in teacher education, and the interaction this entails. The study contributes with research that can be useful in future education. There is a need for further discussions on the subject group and the individual subjects' distinctive character, and about operationalizations of the subjects in school and teacher education.
\end{abstract}

Keywords: practical aesthetic school subjects, conceptualization, school, teacher education

\section{Innledning}

Kroppsøving, kunst- og håndverk, mat og helse og musikk er fag i skolen 1.-10. trinn. Kroppsøving er også et gjennomgående fag for elever i videregående skole. Enkeltfagene er fag i lærerutdanning for grunnskolens 1.-10 trinn. Fagene blir i ulike sammenhenger gruppert som for eksempel «praktisk-estetisk», «de praktiskestetiske fagene» eller «praktiske og estetiske fag». Disse fagene er tradisjonsrike og har historisk sett vokst fram og vært motivert ut fra begrunnelser om danning, kunst og kultur, samfunnsøkonomisk og praktisk nytte (Augestad, 2003; Borgen, 1995; Dale, 1990; Jensen, 2008; Varkøy, 2006). Vi har i en årrekke fulgt pågående diskusjoner, både i allmennheten og i forbindelse med politikkutforming, av faggruppen og disse enkeltfagene i skole og lærerutdanning. Vi har observert stor variasjon i begrepsbruk, omtale, beskrivelser og argumentasjon i vitenskapelige, faglige og populære publikasjoner, og i styringsdokumenter.

I forbindelse med Fagfornyelsen, en reform i grunnopplæringen som i 2020 har hatt et forløp over seks år, viser St. meld. nr. 28 (2015-16) til at «det etterlyses større bevissthet om og satsing» på de praktiske og estetiske fagene fra flere hold 
(s. 48). I forarbeidene, i NOU 2014:7 og i NOU 2015:8, blir fagene omtalt som godt etablerte, men at bredden i de praktiske og estetiske fagene gjør det utfordrende å legge til rette for dybdelæring. I NOU 2015:8 anbefaler utvalget at Fagfornyelsen ikke begynner i det enkelte fag, men i «fagområdene» matematikk, naturfag og teknologi, språkfag, samfunnsfag og etikkfag, og praktiske og estetiske fag. Videre at «når kompetanseområdene skal synliggjøres i læreplanene, må de ulike fagene i hvert fagområde ses i sammenheng» (s. 12). Utvalget etterspør en større faglig diskusjon om hvilken plass og funksjon fagområdet praktiske og estetiske fag skal ha i fremtidens skole i et perspektiv på 20-30 år, og oppfordrer til å «redusere og forenkle, fokusere og tydeliggjøre» (NOU 2015:8, s. 53) og at miljøene innenfor fagområdet gjør prioriteringer.

De praktiske og estetiske fagene har fellestrekk og er ofte omtalt og sett under ett i styringsdokumenter om skole og lærerutdanning, men vi vet lite om hvilke former for samarbeid det har vært mellom fagene, slik det forventes i forbindelse med Fagfornyelsen. Dette har ledet oss til å spørre hvordan de praktiske og estetiske fagene har blitt til, og hvorfor de omtales som, en faggruppe. Formålet med denne artikkelen er å gi et forskningsmessig bidrag som belyser hvordan faggruppen praktiske og estetiske fag konseptualiseres begrepsmessig i et utvalg skriftlige og muntlige kilder om skole og lærerutdanning.

\section{Bakgrunn}

På denne bakgrunn undersøker vi i denne artikkelen historisk konseptualisering (Koselleck, 1985; Skinner, 2002) av de praktiske og estetiske fagene som faggruppe i norsk skole og lærerutdanning, med sin egen organisatorisk-historiske utvikling (Aderback \& Christensen; 2014). Historisk konseptualisering vil her si begrepsdannelse og tolkning ut fra underliggende begreper. Skinner (2002) påpeker at historisk konseptualisering bidrar med andre perspektiver enn historien om konsepter. Vi retter oppmerksomheten mot hvordan konseptualisering av faggruppen og fagene foregår historisk, og hvilke nøkkelhendelser, det vil si eksplisitte så vel som mer implisitte og typisk oversette hendelser (Taylor, Flanagan, Cheney \& Seibold, 2001, s. 101), som kan ha hatt historisk betydning for faggruppen i skole og lærerutdanning.

De praktiske og estetiske fagene beskrives i en rekke rapporter og forskningsartikler som på ulike måter er tett sammenkoblet ideologisk, formelt og operasjonelt (Borgen \& Hjardemaal, 2017; By, 2015; Dahl mfl., 2016; Espeland, Allern, Carlsen \& Kalsnes, 2011; Espeland, Arnesen, Grønsdal, Holthe, Sømoe, Wergedahl \& Aadland, 2013; Telhaug, Mediås \& Aasen, 2006), og ofte skilles det ikke tydelig mellom skole og lærerutdanning. Ifølge Goodlad (1966) sin konseptuelle læreplanteori har læreplanen ulike fremtredelsesformer som må operasjonaliseres i analyser. Innenfor denne læreplanteorien omtales de ulike fremtredelsesformer gjerne som den ideologiske, den formelle, den oppfattede, 
den operasjonaliserte og den erfarte læreplanen (Goodlad, Klein \& Tye, 1979; Gundem, 1990). Goodlads konseptuelle læreplanteori hadde som formål å belyse hvordan læreplaner inngår i et økologisk system av samspill, relasjoner og gjensidige avhengigheter innenfor et nærmere definert domene eller miljø (Doll jr., 1979). Her operasjonaliserer vi styringsdokumenter for skole og lærerutdanning som formelle læreplaner (jf. Goodlad, Klein \& Tye, 1979). ${ }^{1}$ Før vi presenterer problemstillingen og forskningsspørsmålene, skal vi se nærmere på sammenkoblinger mellom skole og lærerutdanning. Forståelse for sammenkoblingene er viktig fordi faggruppen i ulike sammenhenger omtales både generelt som faggruppe i skole og lærerutdanning, og spesielt, som fag 1.10. trinn i skolen og i lærerutdanning for grunnskolens 1.-10. trinn. Vi vil deretter presentere studiens teoretiske perspektiver og eksplorative design, før vi redegjør for resultater og deretter gjør en tematisk diskusjon.

\section{Sammenkobling skole og lærerutdanning}

For å forstå utviklingen av fag i forbindelse med utdanningsreformene bedre, er det nyttig å studere prosessene på faggruppenivå, men dette har i liten grad blitt gjort med de praktiske og estetiske fagene. Selv om det ifølge Østerud, Sunnanå og Frøysnes (2015) er en nær og naturlig sammenheng mellom utviklingen i skole og lærerutdanning, fremstår reformene for disse utdanningsnivåene som to ulike og ikke-synkroniserte utviklingshistorier (Dahl mfl., 2016, s. 42). Dette omtales metaforisk som at skolen og lærerrollen har utviklet seg «lag på lag» og «ulike historiske lag er sedimentert og sameksisterer i nåtiden» (s. 43). Reformer har til hensikt å fornye utdanningers samfunnsrelevans, og historien om utdanningers innhold er historien om kryssende sosiale, kulturelle, politiske og økonomiske interesser (Popkewitz, 2009). I formelle planer og gjennom praksiser utvikles fag historisk og kulturelt, i samspill mellom nasjonale særtrekk, utdanningspolitikk og internasjonale impulser (Naul, 2011).

Reformer i lærerutdanningene begrunnes ut fra reformer i skolen, som medfører behov for endringer i faglig innhold og organisering, grad av profesjonsinnretning, arbeidsformer og kvalitetskrav (Dahl mfl., 2016, s 123), men også ut fra ideer om fremtidens kunnskapsbehov og fremtidig samfunnsutvikling og reformer i høyere utdanning (St. meld. nr. 11 (2008-2009)). Dette gjelder strukturelle forhold som gradsstruktur, finansieringsnøkkel, fagmiljøenes robusthet og kompetanseprofil samt studiepoengproduksjon, studieinnsats, kvalitet, relevans og resultat.

Reformer i skolen begrunnes ut fra fremtidens kunnskapsbehov og ideer om fremtidig samfunnsutvikling. I forbindelse med Fagfornyelsen fremtrer faggruppen etter vår vurdering som konseptuelt uklar. NOU 2014:7 og NOU 2015:8 skriver gjennomgående «praktiske og estetiske fag». I NOU 2014:7

\footnotetext{
${ }^{1}$ Styringsdokumenter for skolen er blant annet opplæringsloven, nasjonale og lokale læreplaner, forskrifter og retningslinjer. For lærerutdanningene gjelder rammeplaner, forskrifter, retningslinjer, programplaner og emneplaner og andre styringsdokumenter for høyere utdanning.
} 
omtales i tillegg musikk som «kunstfag» (s. 87) og faggruppen med bindestrek, som «de praktisk-estetiske fagene» (s. 127). I NOU 2015:8 omtales faggruppen også som «de praktiske fagene og de estetiske fagene» (s. 10), og som "praktiske og estetiske fagområder» (s. 27). Likeledes skriver St. meld. nr. 28 (2015-16) gjennomgående "praktiske og estetiske fag», mens Kirke-, utdannings- og forskningskomiteen (2016) i vedtak 11 i St. meld. nr. 28 (2015-16) i tillegg skriver «de praktisk-estetiske fagene». I fagdebatter i forbindelse med Fagfornyelsen om fagene er også konseptualiseringen vag. For eksempel brukes både «praktiskeestetiske», og "praktiske og estetiske fag» (Rian, 2019), og som enkeltfag omtales musikk og kunst og håndverk som «estetiske fag» (Holdhus \& Christoffersen; 2019, Rian, 2019), og som «kunstfag» (Eriksen, 2014), mens mat og helse og kroppsøving ikke nevnes i denne sammenhengen. Jelstad (2019) knytter kunst og håndverk til «de praktiske fagene», og lignende argumenter finner vi i St. meld. nr. 28 (2015-16), når de praktiske og estetiske fagene omtales som «fag hvor formålet alltid har hatt en særlig praktisk karakter» (s 48).

Vi ser også konseptuelle uklarheter angående fagene som faggruppe i de siste lærerutdanningsreformene. I en utredning i forbindelse med grunnskolelærereformen 2010 (GLU-reformen) går arbeidsgruppen ut fra at praktiske og estetiske fag omfatter «undervisningsfagene kroppsøving, kunst og håndverk, mat og helse og musikk, og skolerelevante fag som drama, dans, med flere» (Espeland, Allern, Carlsen \& Kalsnes 2011, s. 5-6). I utredningens kap. 7 gjøres imidlertid en distinksjon angående praktiske og estetiske fag i den tiårige grunnskolen. Kroppsøving omtales som «noe annet» enn «det estetiske og kunstneriske innslaget i faggruppen representert ved fagene musikk, kunst og håndverk og mat og helse» (s. 39). I en utredning i forbindelse med innføring av femårige grunnskolelærerutdanninger (GLU, 2017), ble de praktiske og estetiske fagene i lærerutdanningene omtalt som bestående av kroppsøving, kunst og håndverk, mat og helse og musikk (Aadland, Borgen, Salvesen, McGuirk, Galaaen \& Oftedal, 2017).

\section{Problemstilling}

Faggruppen fremstår altså i skole og lærerutdanning som konseptuelt mangfoldig i forbindelse med politikkutforming, i styringsdokumenter, utredninger og i offentlige debatter. I forbindelse med Fagfornyelsen er det uttrykt et ønske om at de praktiske og estetiske fagene skal opptre som et samlet fagområde (jf. NOU 2015:8). Det vil kunne bidra til å styrke disse fagene i skolen (jf. St. meld. nr. 28 (2015-16), s. 48) og vil etter vår oppfatning kreve nye typer diskusjoner. Vi har en hypotese om at det å se på fagene som gruppe, kanskje kan bidra til å få øye på hva som samler fagene i stedet for hva som skiller dem. I denne artikkelen er forskningsspørsmålet vårt: Hvordan konseptualiseres faggruppen praktiske og estetiske fag? Våre underspørsmål er følgende: Hvordan er faggruppen, som blir omtalt ved hjelp av ulike kombinasjoner av begrepene "praktisk" og "estetisk", avgrenset begrepsmessig i et utvalg tekster om skole og lererutdanning? Og, 
hvilke nøkkelhendelser kan ha bidratt til konseptualiseringen av faggruppen i skole og lcererutdanning?

\section{Teoretiske perspektiver}

Som det fremgår over varierer det hvordan de praktiske og estetiske fagene som faggruppebetegnelse brukes, hvem som sier hva når, og hva det refereres til i ulike kontekster. Dette er en utfordring når fagene forventes å samordne seg som fagområde og klargjøre sitt felles bidrag i grunnopplæringen i Fagfornyelsen (jf. NOU 2015:8). Konsepter kan gi grunnlag for måter å tenke og handle på, og sier samtidig noe om det de representerer, men disse betydningene må ses $\mathrm{i}$ den sammenheng konseptene produseres i, hevder Blunder (2012). Historikerne Koselleck (1985) og Skinner (2002) undersøker begrepers betydning sosialt og politisk, samt endring og transformasjon av begreper over tid (Palonen, 2002). Sammen representerer Koselleck og Skinner en kritikk av den ahistoriske og politiserende bruken av konsepter i historieforskningen (Palonen, 2002). Skinner er mest opptatt av retoriske reformuleringer av konsepter i sammenheng med argumentasjon i politikkutforming. Ingen konsepter kan ha definisjoner eller standardbetydninger, konseptualisering må forstås gjennom konteksten, og analyse av begrepenes retoriske bruk er en måte å koble politisk språk til politisk handling (Stråth, 2005, s. 530-531). Koselleck er opptatt av at transformasjoner skjer på et sosialpolitisk nivå, og at konsepters historie er en form for sosialhistorie, der betydning og konstellasjoner og konseptualiseringens logikk endres over tid (Stråth, 2005, s. 531). Stråth trekker frem at Skinner og Koselleck gjennom sine tilnærminger får frem «uordenen» i begrepers historie.

Denne kritisk-historiske tilnærmingen finner vi nyttig, og den har metodologiske konsekvenser for vår studie. Derfor anvender vi her Koselleck (1985) sin forståelse av at det å undersøke begreper historisk innebærer å se temporær tid i sammenheng med oppfattet tid. Koselleck (1985, s. xxiii) stiller spørsmål om hvordan, i en gitt nåtid, temporære tidsdimensjoner av fortid og nåtid er relatert. Spørsmålet innebærer ifølge Koselleck en hypotese om at erfaringer er knyttet til forventninger både i fortid og fremtid. Erfaringer og forventninger har å gjøre med tid og rom; «space of experience» og «horizon of expectation» knytter an til minner og håp, og til muligheten for at historie er tenkelig (Koselleck, 1985, s. 270). Utdanningsreformer er et eksempel på hvordan «space of experience» og «horizon of expectation» fungerer formativt. Behovet for nye reformer begrunnes i ideer om fremtidige samfunnsbehov, ut fra erfaringer i fortid og hvordan disse erfaringer fremtrer i nåtid. Dahl mfl. (2016) beskriver de siste tiårenes reformer i skole og lærerutdanning allegorisk som at «gamle og nye krav og forventninger, eksisterer side om side i en skjør og uklar balanse» (s. 42). På samme måte er fagene i skolen tidsbetingede forsøk på å gi svar på spørsmål om noe i verden, og 
de viser hvordan erfaringer organiseres, prinsipper formuleres og hvordan teorier og lovmessigheter bygges (Steinsholt, 1997).

Kunnskap er også omsluttet av spørsmål om makt, historie, posisjoner, legitimering og autonomi (Bourdieu, 1988). Innenfor de praktiske og estetiske fagene mener vi dette særlig kommer til uttrykk i hvordan noen av fagene gjerne omtales som «praktiske», mens andre omtales som «estetiske» fag og som kunstfag. Spørsmål om makt, legitimering og autonomi er avgjørende for den relative posisjonen til enkeltfagene i skolen så vel som i lærerutdanning, for eksempel med tanke på ressurser i form av timer, økonomi, kompetansekrav, etc. De ulike betegnelsene av faggruppen, som praktisk-estetiske fag, de praktiskestetiske fagene eller praktiske og estetiske fag, kan være uttrykk for slike kamper og posisjoneringer, ved at betegnelsene fremstår som tradisjonelle, samtidig som de også er situasjonsbetingede og i stadig endring.

\section{Konseptualiseringer av "praktisk» og «estetisk»}

«Praktisk» og «estetisk» utgjør som et begrepspar kjernen i betegnelsen på faggruppen. Begrepspar har asymmetriske historisk-kulturelle referanser som både er fortidige og nåtidige, og er referanser som stadig blir omplassert, samtidig som de brukes som om de refererer til noe entydig og konstant, ifølge Koselleck (1985). Vi vil her søke å skape større klarhet i hva slags asymmetrier begrepsparet "praktisk» og «estetisk», i faggruppen, omfatter.

«Praktisk» knyttes i dagligtale til handling, det å utføre et arbeid eller en virksomhet, som «(å gjøre) noe praktisk». Det fins en omfattende vitenskapelig litteratur om praktisk kunnskap. Molander (1993) diskuterer hvordan den «praktiske kunnskapen» vanligvis underordnes den teoretiske, som noe før teori og som noe mindre verdig enn teori. Denne asymmetrien er dypt rotfestet i vestlig vitenskap og filosofi. Gjennom en kunnskapsteori for «kunnskap i handling», med referanse til Wittgensteins språkfilosofi, argumenterer Molander (1993) derimot for at menneskelige handlinger er grunnleggende for våre begreper og kunnskap (jf. Wittgenstein, 1969/1992, paragraf 204, s. 35). Den teoretiske kunnskapen er i endring og usikker, praktisk kunnskap er definitiv og påtagelig, materialisert og brukt (Molander, 1993, s. 19). Molander (1993) diskuterer slike forståelser og hevder at vekslingen mellom del og helhet, nærhet og distanse, kritikk og tillit, handling og refleksjon er grunnleggende for innlæring og kunnskap i handling. Kunnskap i handling er slik sett ikke bare handlinger, men også begreper, kontekst og historie. «Praktisk» kan altså innenfor de praktiske og estetiske fagene vise til ulike kunnskapsforståelser, både referere til noe som oppfattes som underordnet, og til at det er noe grunnleggende i forhold til kunnskap, slik Molander (1993) argumenterer for.

Begrepet estetikk har opprinnelse i det greske aisthetikos (sansende), og ble introdusert av Baumgarten i verket Aesthetica fra 1750, som betegnelse for «vitenskapen om den sanselige erkjennelse» (2008, s.11). Kunstens rolle i erkjennelsen har vært diskutert i filosofien siden antikken. Med Baumgarten, som 
sidestilte den estetiske dimensjon i erfaring og erkjennelse med rasjonelle forestillinger og slutninger (Jørgensen, 2018), og Kant, som tematiserte den estetiske erfaringen i Kritikk av dømmekraften fra 1790, ble både kunsten og den estetiske erfaringen selvstendiggjort (Kittang, 1991, s. 73). Dermed ble ikke kunstens verdi sett primært som dens evne til å formidle et (moralsk) budskap, snarere er «(K)kunsterfaring (er) verdfull på sine eigne autonome premissar, fordi den gir oss øving i å «bruke» dei transendentale medvitskreftene (i kantiansk forstand) som er føresetnaden for våre liv som erkjennande og moralske vesen" (s. 73). «Estetisk» kan altså innenfor de praktiske og estetiske fagene referere til noe som erfares gjennom kunsten, men også som noe som inngår i alle erfaringer, også praktiske erfaringer.

Når vi så vender oss til litteraturen om de praktiske og estetiske fagene i skole og lærerutdanning, ser vi at «praktisk» og «estetisk» hovedsakelig diskuteres som utgangspunkt for danning og læring i skolen, og vi bruker dette som eksemplifisering. Det beskrives en spenning mellom vektlegging av kunnskapens subjektive sider, som innebærer at eleven og elevens estetiske erfaringer er i sentrum, og vektlegging av innholdet, kunnskapens objektive sider, som formidles til elevene (Lindgren \& Ericsson, 2013). I Norden fins en sterk diskurs om det estetiskes frigjørende potensial i opplæringen som vektlegger elevens subjektive estetiske erfaring. Likevel fremtrer «estetisk» som noe uklart og diffust ifølge studier av læreplaner og operasjonaliserte praksiser i skolen (Thorgersen \& Alerby, 2005). Schou (2005) påpeker hvordan dette paradoksalt fører til at den «(...) romantiske forståelse av det skapende frie individet» i de praktiske og estetiske fagene i skolen skapes gjennom at elever presenteres for «den kulturelle kanon» som en form for standardisering (Schou, 2005). Vi observerer at i litteraturen om de praktiske og estetiske fagene i skolen framskrives konflikter mellom kunnskapens subjektive og objektive sider (Lindgren \& Ericsson, 2013). Dette foreslås løst ved at de estetiske fagene, også omtalt som kunstfagene, får en styrket posisjon i skolen (Bamford, 2006; Borgen, 2011), og kan knyttes til en forståelse av at vi trenger øvelse når det gjelder estetiske erfaringer (Kittang, 1991). Andre studier (Hetland \& Winner, 2004; Winner, Goldstein \& VincentLancrin, 2013) hevder at det er gjennom praktisk prosedyrekunnskap at flere praktiske og estetiske fag i skolen kan bidra til kunnskaper og kompetanser som elevene kan overføre til andre fag og erfaringsområder. Borgen og Hjardemaal (2017) påpeker at elevenes subjektive erfaringer i de praktiske og estetiske fagene ikke kan separeres fra kunnskapens objektive innhold, og læring og utvikling av kompetanse i bred forstand.

«Det er ikke slik at enkelte fag egner seg for utvikling av tenking i begreper, mens andre ikke gjør det» hevder Dale (2010, s. 115). Han har kritisert både den «tradisjonelle kunnskapsskolen og den reformpedagogiske, naturalistiske og ekspressive motreaksjonen i det 20. århundret» (Dale, 1990, s. 123) og argumentert for at å skille mellom teoretiske fag og det kognitive på den ene side og «praktisk-estetiske fag» på den andre er uholdbart (2008, s. 199). Et lignende 
argument er trukket frem av Vindenes (2008) om hvordan teori og praksis er nært sammenvevd under innøving av et musikkstykke, og han forklarer hvordan teorien blir utformet praktisk, dvs. som klingende musikk.

I en analyse av Kunnskapsløftet (LK06) som læreplan diskuterer Dale (2008) tenkemåten at «skolefaglig kunnskap» i hovedsak er teori om noe, og at «ferdighet» i hovedsak er praktisk utøvelse (s. 88). Med eksempler fra fagene i skolen gjennomgår Dale betydningen av handling for læring. Abstrakte ordforklaringer spiller ikke noen rolle i den første innlæringen av et (fag)språk (s. 90). Med fageksempler i matematikk og mat og helse viser Dale til hvordan ord, symboler og setninger «veves sammen med elevenes handlinger» (s. 91), og at fagordene er et sosialt produkt og oppstår ved deltagelse i sosiale erfarings- og handlingsprosesser (s. 94). Dale (2008) viser videre til at det er viktig for elevenes læring at de får løse praktiske oppgaver der de har bruk for språket i kombinasjon med handling (s. 103). Det estetiske kommer på den ene side til uttrykk i alle fag i måten deres kunnskaper uttrykkes, på den andre side som språkliggjøring som særlig kan forekomme i de praktisk-estetiske fagene (Dale, 2008, s. 198-202). I gjennomgangen av læreplanene i LK06 hevder Dale (2008) at faget mat og helse gir en innfallsvinkel til estetisk oppdragelse som er verd å ta vare på, der forhold i faget som mat, smak og kultur, helse og livsstil legger til rette for refleksjon om og erfaringer med praktiske sider ved estetisk kunnskap (s. 203). Når Dale bruker bindestrek i fagbetegnelsen "praktisk-estetiske fag» er det ut fra en slik forståelse.

Ulike kombinasjoner av «praktisk» og «estetisk» er konseptualiseringer av forståelser, verdier og perspektiver som er betydningsfulle på bestemte måter. Hva som legges i betydningen av bindestreken, et og, eller mellomrommet mellom ordene, forblir likevel i skyggen av konseptualiseringens funksjon i ulike formelle dokumenter som vi undersøker her. Mens en bindestrek binder sammen deler av et ord, er og en konjunksjon som binder sammen ord. De ulike sammensetningene av begrepsparet kan slik sett ha flere betydninger, for eksempel kan «praktiske og estetiske» si noe om at fagene i faggruppen er like og sidestilles, eller at fagene er helt ulike, men sidestilles. Koselleck (1985) og Skinner (2002) hevder begge at ethvert konsept kun har historie og må undersøkes historisk, og at vi må undersøke synspunkter og roller et konsept, eller et sett konsepter, har i hendelser. Dette innebærer her også utforsking av nøkkelhendelser (Taylor mfl., 2001) for faggruppen. Disse perspektivene utgjør grunnlaget for å kunne belyse ulike konseptualiseringer av faggruppen praktiske og estetiske fag.

\section{Metode og datagrunnlag}

Vi valgte et eksplorerende design (Hellevik, 1994, s.77) som innebar kollektive drøftelser, for å nærme oss spørsmålet hvordan faggruppen, som blir omtalt ved hjelp av ulike kombinasjoner av begrepene «praktisk» og «estetisk», er 
konseptualisert i tekster om skole og lærerutdanning. Vi startet med å søke etter begrepene «praktisk» og «estetisk» i skrevne kilder fra hvert av de fire fagene, kroppsøving, kunst- og håndverk, mat og helse og musikk, skrevne kilder som var tilgjengelige ved institusjonens bibliotek, også i arkivet. Videre benyttet vi oss av Nasjonalbibliotekets database, som inneholder betydelig flere dokumenter av potensiell interesse. Her erfarte vi at verken søkegrensesnittet eller trefflistene ga oss det vi ønsket, nemlig en rimelig sikkerhet om at vi ville lykkes med å sirkle inn relevante dokumenter for å belyse problemstillingen. Vi så også at det ikke ville være håndterbart innenfor artikkelens rammer å foreta et systematisk søk.

Vi valgte å bruke tjenesten NB N-gram ${ }^{2}$ til å skaffe oss et historisk bilde av forekomsten av de ulike begrepene og kombinasjonene av dem i hele korpuset. Dette omfatter et materiale fra 1810 til og med september 2013 og er godt egnet for å undersøke historisk konseptualisering (Boassen \& Malvik, 2019). Søket tillater bare kombinasjoner av inntil tre ord. Derfor får vi ikke med så mye av konteksten ordene står i. Vi har ikke gått systematisk gjennom alle forekomstene og deres kilder, men det er sannsynlig at det er noe duplisering. For eksempel kan meldinger til Stortinget både foreligge enkeltvis og som del av de overordnede dokumentene Stortingsforhandlinger. ${ }^{3}$ NB N-gram-tjenesten er derfor bare egnet til å gi et oversiktsbilde over bruken av begrepene og ordkombinasjonene, og til å vise tendenser over tid. Vi har søkt på hele perioden korpuset dekker, og figurene viser relevante utdrag, altså de årene vi fikk treff.

En summativ tilnærming kan bidra til å kartlegge utvalgte aspekter av et forskningsfelt (Hermansen, Lorentzen, Mausethagen \& Zlatanovic, 2018, s. 5), noe vi fant hensiktsmessig. For å finne svar på hvordan faggruppen er avgrenset begrepsmessig i tekster om skole og lærerutdanning, søkte vi etter begrepene «praktisk» og «estetisk» i samtlige styringsdokumenter som omhandler utdanningspolitikk og skolehistorie i Nasjonalbibliotekets database. Dette var styringsdokumenter som NOUer, stortingsmeldinger, læreplaner, handlingsplaner og litteratur som omhandler utdanningspolitikk og skolehistorie. Vi foretok en ytterligere avgrensning og tok utgangspunkt i ulike typer dokumenter for grunnskolen 1.-10. trinn og lærerutdanning for grunnskolens 1.-10. trinn fra perioden 1960 til 2020 som søkene i NB N-gram hadde vist var mest aktuelle. En tidslinje, (se figur 3 i resultatkapitlet) med stortingsmeldinger for grunnskole, lærerutdanning og høyere utdanning, læreplaner for grunnskolen og planer for lærerutdanning ble utviklet på grunnlag av informasjonen fra søkene i NB N-gram

\footnotetext{
${ }^{2}$ NB N-gram ${ }^{\text {BETA }}$ fra Nasjonalbiblioteket gjør det mulig å søke i store deler av deres materiale etter forekomst av bestemte ord og ordfrekvenser. NB N-gram omfatter aviser og bøker (en kategori som også omfatter rapporter, offentlige dokumenter og annet) fra 1810 til og med september 2013, til sammen omlag 34 milliarder ord. (Nasjonalbiblioteket, 2015.)

${ }^{3}$ Nasjonalbiblioteket (2015) tar følgende forbehold: «NB N-gram ${ }^{\text {BETA }}$ er under utvikling, og tjenesten kan derfor til tider være ustabil. På dette stadiet kan vi ikke garantere at resultatene vil være helt identiske mellom oppdateringer, selv om dette er noe vi etterstreber. Tekstene som ligger til grunn for tjenesten er skannet og automatisk korrekturlest, noe som kan føre til en del feil i det underliggende materialet. Særlig gjelder dette for de eldre tekstene.»
} 
av hele korpuset, for å kunne besvare første delproblemstilling, hvordan konseptualiseres faggruppen praktiske og estetiske fag?

For å undersøke hvilke nøkkelhendelser som kan ha bidratt til konseptualiseringen av faggruppen i skole og lærerutdanning, gjennomførte vi individuelle semistrukturerte intervjuer. ${ }^{4} \mathrm{Vi}$ foretok et pragmatisk utvalg (Kvale \& Brinkmann, 2010) av sentrale personer med mer enn 25 år i lærerutdanning, fra kroppsøving, kunst og håndverk, mat og helse og musikk, og/eller andre sentrale posisjoner, fra seks ulike institusjoner. Felles for alle informantene var at de har erfaring som lærere fra grunnopplæringen, har mer enn 25 år i universitets- og høgskolesektoren, har vært med i ulike regionale eller nasjonale læreplanrevisjoner og annet utredningsarbeid som del av sitt arbeid innenfor faget, og har publisert tekster innenfor sitt fagfelt. I dag er alle enten pensjonister eller emeritus/emerita. Intervjuene dreide seg om informantenes forståelse av begrepsparet «praktisk» og «estetisk» i relasjon til eget fagfelt, og hva de mente var de viktigste nøkkelhendelsene innenfor deres fagfelt og/eller i lærerutdanning. Intervjuene ble tatt opp på lydfil og transkribert. En individuell og felles lesning av transkripsjonene har dannet grunnlaget for en felles tematisk analyse av intervjuene. I analysefasen valgte vi å foreta en kategorisering, i tråd med Sollid (2013), og systematiserte uttalelsene i grupper som var bestemt på forhånd. I tråd med forskningsspørsmålet hadde vi forhåndsbestemt en hovedgruppe, nemlig nøkkelhendelser, som kunne peke på viktige hendelser som eksplisitt og mer implisitt kan ha hatt historisk betydning innenfor tidsperioden vi undersøker. Hver for oss og kollektivt skrev vi notater for å overvåke hele analyseprosessen, deretter diskuterte vi våre notater og valgte sitater til bruk i artikkelen.

\section{Resultat}

Resultatene er gruppert i tre deler. Først presenteres resultater av søk i NBs Ngram på ulike kombinasjoner av «praktisk» og «estetisk», i kombinasjon med «fag» i hele korpuset. Her er figurene bilder av søket i NB N-gram, slik at hvis noen vil gå inn og etterprøve det vi har gjort, kan de gjenkjenne resultatet. Videre presenterer vi en tidslinje med utvalgte dokumenter som inneholder disse ordkombinasjonene, og som er styringsdokumenter i forbindelse med reformer i grunnopplæring, lærerutdanning og høyere utdanning. Til sist presenterer vi nøkkelhendelser som fremkommer i intervjuer.

\section{Søk med ulike kombinasjoner av «praktisk» og "estetisk»}

Ved søk i NB N-gram på ordene praktisk og estetisk, forbundet med henholdsvis og, og bindestrek, i entall og flertallsform, og i kombinasjon med ordet fag, er

\footnotetext{
${ }^{4}$ Vi søkte NSD om godkjenning til å gjennomføre semistrukturerte intervjuer, og prosjektet ble godkjent 09.01.18 (NSD, 57660).
} 
resultatet som det fremgår av figur $1 .^{5}$ Treffene på søket «praktisk-estetiske fag» inngår i treffene på «praktisk-estetiske» og «praktisk-estetisk fag» i «praktiskestetisk». Derfor følger kurvene for disse ordfrekvensene hverandre nært.

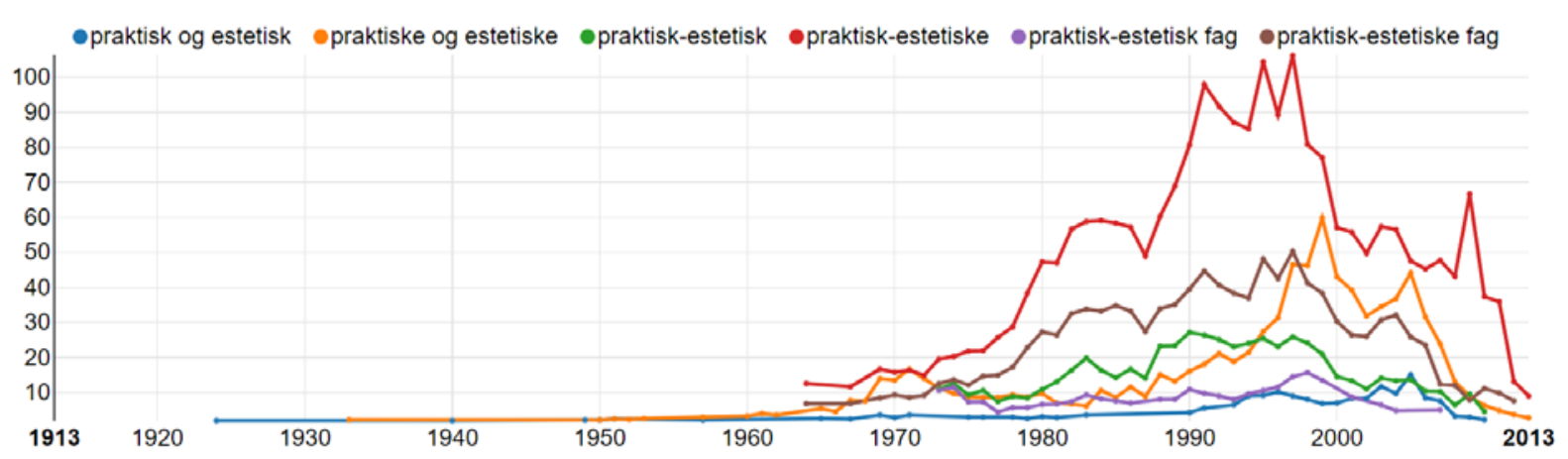

Figur 1: Forekomst av ordene «praktisk» og «estetisk», forbundet med henholdsvis og, og bindestrek, i entall og flertallsform, og i kombinasjon med ordet fag ved søk i NB N-gram.

Ordkombinasjonene opptrer første gang i 1924. De følgende 40 årene ser vi noen få forekomster av kombinasjonene "praktisk og estetisk» og «praktiske og estetiske». I 1964 dukker "praktisk-estetiske» og "praktisk-estetiske fag» i flertallsform opp. Den første forekomsten av «praktisk-estetisk fag» i entallsform har vi i 1973. Vi ser et betydelig oppsving av flere kombinasjoner, spesielt "praktisk-estetiske» og «praktisk-estetiske fag» fra 1976. Aller mest er ordkombinasjonen brukt i tiåret 1987 til 1997. Fra midt på 1990-tallet gjør også ordsekvensen «praktiske og estetiske» seg gjeldende, og i årene 1999 og 2005 forekommer den nesten like ofte som «praktisk-estetiske» med bindestrek. Basert på figur 1 viser vi i tabell 1 antall forekomster av ulike ordkombinasjoner av «praktisk» og «estetisk» i hele korpuset vi undersøkte i NB N-gram.

Tabell 1: Antall forekomster av de ulike ordkombinasjonene i hele korpuset i NB N-gram

\section{Søketerm}

praktisk og estetisk

praktiske og estetiske

praktisk-estetiske

praktisk-estetisk

praktisk-estetisk fag

praktisk-estetiske fag

praktisk-estetisk IKKE fag

praktisk-estetiske IKKE fag

\section{Forekomst}

202

903

2205

563

260

1060

303

1145

Figur 2 viser treff i NB N-gram på «praktisk fag», «praktiske fag», «estetisk fag», «estetiske fag», og "praktisk-estetiske fag». «Praktiske fag» dukker opp allerede i 1859, og figurerer jevnlig med noen få forekomster fra midt på 1890tallet til midt på 1940-tallet. Fra da stiger det med noen få unntak, og har topper i

\footnotetext{
${ }^{5}$ Alle våre søk er gjort på begge målformer, uten skille mellom stor og liten forbokstav, og i hele perioden korpuset dekker. Her vises relevante utsnitt. Vi har sett på absoluttfrekvens, altså antall forekomster av våre ordkombinasjoner.
} 
1980 og rundt 2000. «Estetiske fag» dukker først opp i 1957, og stiger temmelig bratt fram mot århundreskiftet. Etter et lite fall rundt år 2000, stiger det voldsomt i 2003, før det faller like bratt igjen. Vi ser at flertallsformene «praktiske fag» og «estetiske fag» forekommer betydelig oftere enn de tilsvarende entallsformene fra 1960-tallet av, og også betydelig oftere enn kombinasjonen «praktisk-estetiske fag».

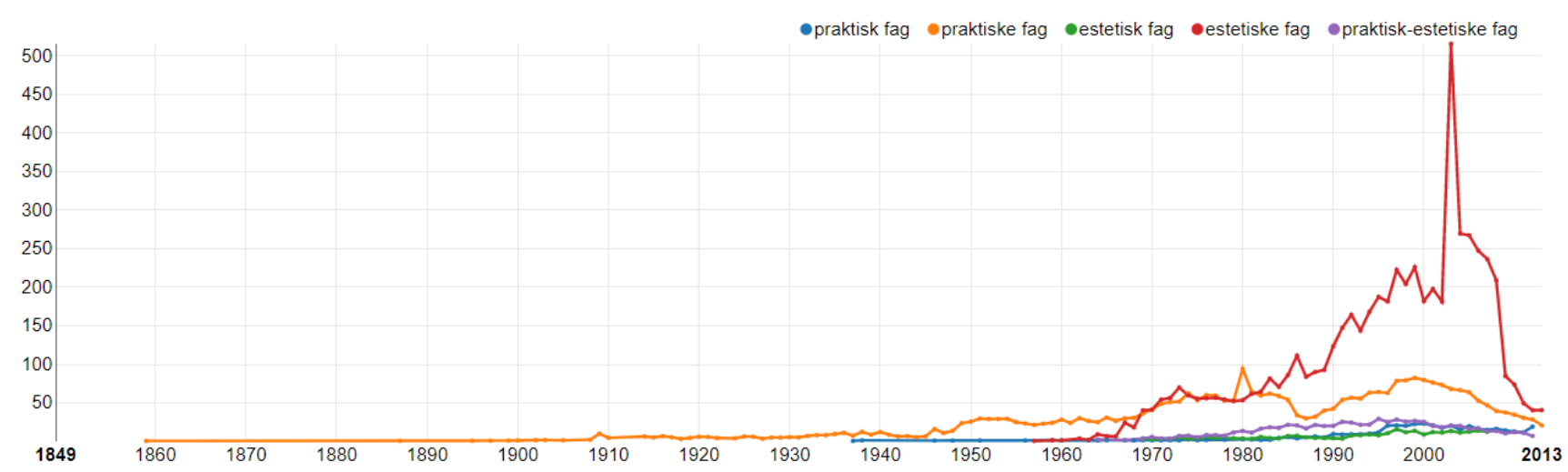

Figur 2: Forekomsten av «praktisk» og «estetisk» i kombinasjon med «fag».

\section{En tidslinje med dokumenter om skole og lærerutdanning}

Tidslinjen, figur 3, viser 29 utvalgte dokumenter fra 1960 til 2020. De utvalgte styringsdokumentene som tidslinjen er en oversikt over, representerer viktige utdanningspolitiske hendelser fagene konseptualiseres i og gjennom i forbindelse med reformer i skole og lærerutdanning, og er slik sett eksplisitte nøkkelhendelser. Begrunnelsene for å velge dette tidsrommet er for det første, som det fremgår av figur 1, at det er fra 1964 «praktisk-estetiske fag» først opptrer i flertallsform som betegnelse for flere fag i en gruppe. Videre, når tidslinjen inkluderer dokumenter etter 2013 (jf. korpuset i NB N-gram) er det for å illustrere hvordan dokumentene før 2013 står i en kontekst med videre politikkutforming frem mot Fagfornyelsen i 2020. Av hensyn til visuell lesbarhet og omfang ble andre styringsdokumenter som NOUer, Stortingsforhandlinger, lover og regelverk ikke inkludert i tidslinjen. Se appendix 1 for referanser til dokumentene på tidslinjen. 


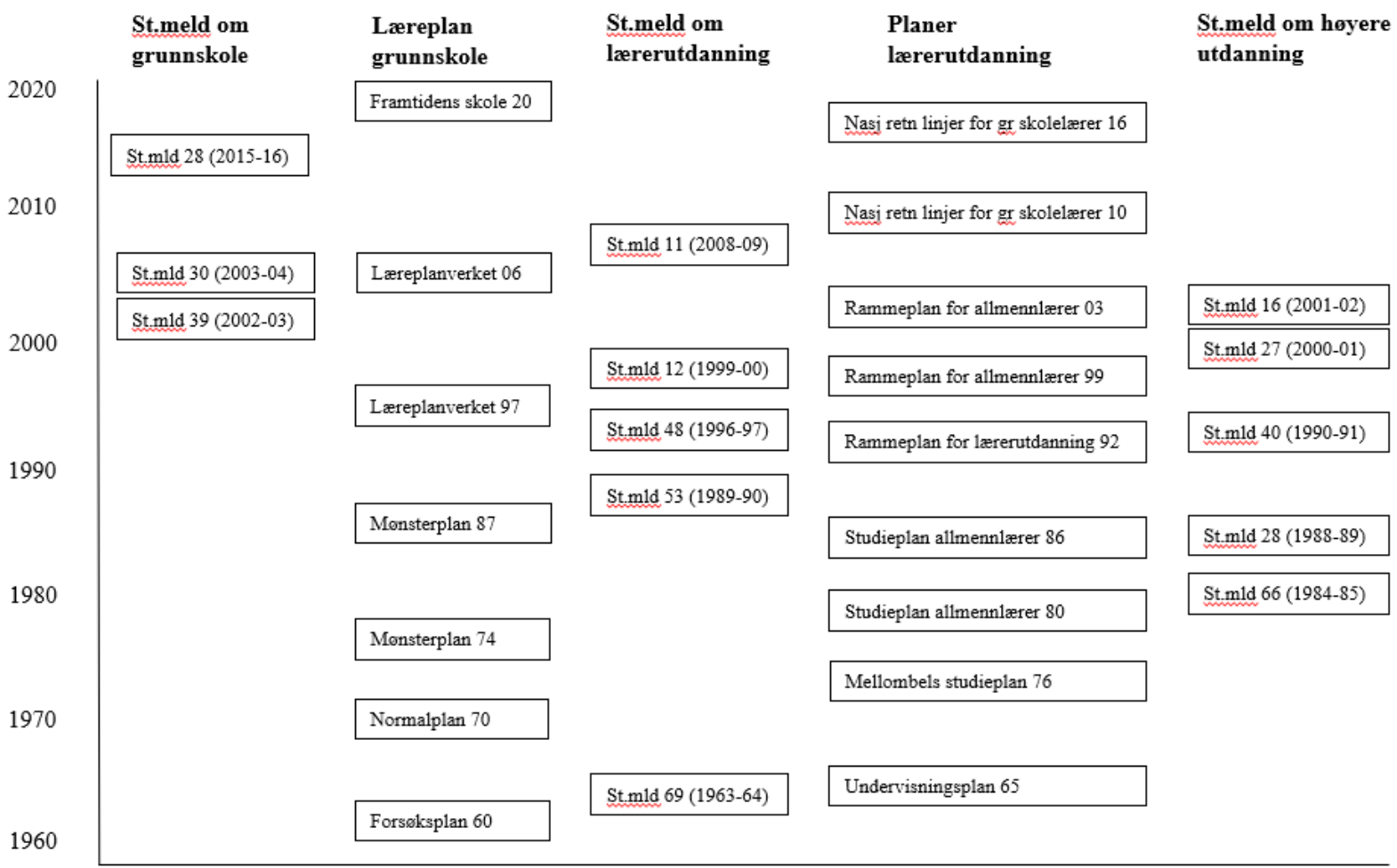

Figur 3: Tidslinje fra 1960 til 2020 med styringsdokumenter i forbindelse med reformer i grunnopplæring, lærerutdanning og høyere utdanning.

\section{Oppfatninger om faggruppen og om nøkkelhendelser}

I en tematisk analyse av intervjuene fremkommer ingen felles oppfatning av begrepsparet «praktisk» og «estetisk». Når det gjelder hvilke fag i skolen informantene mente var en del av faggruppen, nevnte flere av informantene fagene kroppsøving, kunst og håndverk og musikk, og viste til at heimkunnskap/mat og helse kom til etter hvert. En av informantene omtalte faggruppen i skole og lærerutdanning generelt, og argumenterte for at de estetiske fagene i noen miljøer er sett på som kunstfag, eksemplifisert med «dans, drama, kunst og håndverk, musikk, medier og norsk», og stilte retorisk spørsmålet «hvem vil være et praktisk fag?» Denne informanten var opptatt av konseptualisering, og brukte formen "praktiske og estetiske fag» om faggruppen. Dette ble begrunnet med at et $o g$ innebærer at det er to ulike grupper fag, og sa «for folk flest så ligger det veldig lite status og legitimitet i å være et praktisk fag». En annen informant trakk frem at fellesnevner for faggruppen er at de har spesialrom både i skole og lærerutdanning, og at «de skal ha en sterk utøvende del, som da forankrer seg i det litt vanskelige ordet praksis...praktisk. Og så skal fagene ha estetisk dimensjon, så det er den kombinasjonen av det å utøve, og det å oppleve og sanse.» I tillegg påpeker denne informanten at fagene i grunnskolen kan være forberedelse til ulike utdanningsprogram i videregående opplæring.

Når det gjelder nøkkelhendelser, viser informantene til ulike forhold som eksplisitt og mer implisitt kan ha hatt historisk betydning for faggruppen i skole og lærerutdanning. Flere nevner strukturreformene i høyere utdanning som ressurskrevende, og en informant påpeker at «det tok noen år, kanskje, før en 
kunne arbeide målrettet med disse fagene igjen». Ifølge informanten i musikk førte strukturendringene i høyere utdanning, spesielt ny økonomistyringsmodell, blant annet til at årsenheter i musikk og musikklinjer gradvis forsvant. I kroppsøving mener en informant at strukturreformene fra distriktshøgskoler og lærerskoler til høyskoler på 1990-tallet fikk konsekvenser for «fagets status». I kunst og håndverk nevner en informant at denne reformen virket sammen med reformer i grunnopplæringen. Samtidig med Reform 94 i videregående opplæring ble det krav om studiekompetanse til høyere utdanning, og «det ble en stor forandring i kompetansen som studentene hadde» i faget når de kom til høyere utdanning, og manglet forkunnskaper som studenter tidligere hadde.

Nøkkelhendelser i grunnopplæringen knyttes til enkeltfag. En nøkkelhendelse som ble trukket frem innenfor mat og helse er navneendringen i grunnopplæringen fra heimkunnskap til mat og helse i LK06. Ifølge denne informanten var det bred enighet om at «faget ikke skulle gå så nært familien», og ønske om et mer samfunnsmessig relevant fag som kunne «løfte faget til å bli et mer allmenndannende fag på matområdet». En nøkkelhendelse som ble trukket frem av en av informantene innenfor kunst og håndverk var navneendringen da forming ble erstattet med kunst og håndverk i læreplanreformen L97. Dette var bra, for dette fikk frem kunsten i faget, men informanten var mer ambivalent til håndverksbegrepet; «vi var jo bekymra for at det skulle gå tilbake til det nitide og lite kreative, da, men sånn ble det vel ikke. Tror jeg.»

Alle informantene trakk frem at de mange reformene i høyere utdanning og et økende krav til akademisering har påvirket praksis i lærerutdanningen. En informant sa at Lov av 8. juni 1973 nr. 49 om lærerutdanning (Kirke- og undervisningsdepartementet, 1973), var «voldsomt viktig!». Da fikk lærerhøgskolene anledning til å ha hovedfag, og «den er grunnlaget for den, hvis vi skal bruke ordet, akademiseringen, som har vært mulig siden», «og så er det masse kompetanse som er kommet ut av det, og annerledes kompetanse». En annen informant hevdet at eget fag er satt til side i alle reformene. Informanten «har lyst å gå med sørgebind, de praktiske fagene er døde (i lærerutdanning)». En tredje brukte retorisk «doktorgradsdødaren» om akademiseringen i høyere utdanning.

\section{Drøfting}

Vi undersøker konseptualiseringen av faggruppen. Når vi gjør en analyse av konseptualisering vil kontekst være like viktig som utsagn (Koselleck, 1985; Skinner, 2002), og det som var før og det som er nå må ses i relasjon til forventninger om fremtiden (Koselleck, 1985). I tråd med Goodlads læreplanteori og ved hjelp av ulike konseptualiseringer, viser denne studien hvordan «praktisk» og «estetisk» fremtrer historisk i ulike kombinasjoner eller hver for seg, og sammen med «fag», i dokumenter om skole og lærerutdanning. 


\section{Retorisk bruk av og eller bindestrek i politikkutforming}

En mangeårig og stadig pågående diskusjon angående de praktiske og estetiske fagene som faggruppe og enkeltfag, kan forstås som forårsaket av de betydninger konseptualiseringen til enhver tid blir tillagt i det samspillet de inngår i (Blunden, 2012). Fra gjennomgangen av litteratur om de praktiske og estetiske fagene ser vi at ulike forståelser av fagenes egenart og bidrag i skolen er gjeldende, og dette gjenspeiles i dokumentene som ligger til grunn for denne studien. Figur 1 og tabell 1 viser for eksempel at fra 1964 opptrer flertallsformen praktisk-estetiske fag for første gang, og denne nye samlebetegnelsen kan leses som symptomatisk for en ny vilje til å se på disse fagene som en gruppe. Tabell 1 viser at ulike former for ordkombinasjoner av praktisk-estetisk med bindestrek opptrer langt hyppigere enn kombinasjoner med og. Figur 1 viser at fra midt på 1990-tallet fremtrer flertallsformen «praktiske og estetiske» igjen etter et opphold, og i årene 1999 og 2005 forekommer denne formen nesten like ofte som «praktisk-estetiske» med bindestrek. Dale (2008) hevder at bindestreken er en nødvendighet for å uttrykke sammenhenger i faggruppen. En informant trekker derimot frem at et $\mathrm{og}$ markerer forskjell i status på praktiske og estetiske fag, og viser til praktisk som noe underordnet (jf. Molander, 1993). Dette kan kanskje tyde på at det på 1990-tallet og fremover 2000-tallet fins ulike forståelser av faggruppen, der bruken av og kan forstås som uttrykk for asymmetri. Ord-kombinasjoner av «praktisk» og «estetisk», med eller uten et og eller en bindestrek kan slik betraktes som språklige konstruksjoner som benyttes retorisk i forbindelse med politikkutforming (Skinner, 2002).

\section{Reformer i høyere utdanning - kompetansekrav og akademisering}

En forklaring på hvordan «praktisk» og «estetisk» fremtrer historisk i ulike kombinasjoner kan også knyttes til at reformbestrebelser i skole og lærerutdanning ofte møter sektorspesifikke historiske og kulturelle tradisjoner som skaper debatt (Aasen, Prøitz \&Rye, 2015). Dette kan ha sammenheng med det Olsen (2007) omtaler som manglende samsvar mellom mål og ambisjoner, og valg av virkemidler i utdanningsreformer. Av figur 3, tidslinjen, fremgår det hvordan styringsdokumentene står i en bredere kontekst og i forhold til hverandre. Det er særlig mange dokumenter angående lærerutdanning de siste tiårene. En grunn kan være det høye reformtempoet i lærerutdanning både som følge av politiske vedtak om endringer i skolen og som følge av vedtak om endringer i høyere utdanning (Dahl, mfl., 2016, s. 121). Informantene vektlegger reformer i høyere utdanning som mer implisitte enn eksplisitte nøkkelhendelser for de praktiske og estetiske fagene i skole og lærerutdanning. Ved krevende reformer i høyere utdanning ble fagene nedprioritert, samtidig fikk reformer i skolen konsekvenser for elevenes kunnskapsgrunnlag i fagene, noe som blant annet har betydning ved opptak til lærerutdanning i disse fagene. Sett i lys av figur 1 og 2 kan store variasjoner i ordkombinasjoner og enkeltord forstås slik Stråth (2005) viser til, at begrepenes retoriske bruk er en måte å koble politisk språk til politisk 
handling. Her kan blant annet diskusjonene om navneendringer på fag ha hatt betydning som eksplisitte nøkkelhendelser. En informant var inne på dette i begrunnelsen for at ordkombinasjonen praktiske og estetiske fag best gjenspeiler enkeltfagenes relative status og legitimering $i$ faggruppen. Ulike ordkombinasjoner kan ha blitt oppfattet ulikt og brukt retorisk i lokale, regionale og nasjonale fagpolitiske prosesser der informantene oppgir at de har bidratt $\mathrm{i}$ sammenheng med utdanningsreformer.

Ifølge Østerud, Sunnanå og Frøysnes (2015) kan norsk lærerutdanning fra 1945 og frem til i dag karakteriseres som en utvikling i spenning mellom tradisjon og fornying. Reformene i høyere utdanning har ført til økende krav om akademisering. Lov av 8. juni 1973 nr. 49 om lærerutdanning (Kirke- og undervisningsdepartementet, 1973) som ga mulighet til hovedfag kan forstås som en eksplisitt nøkkelhendelse tilbake i tid, som senere har hatt en mer implisitt betydning for de praktiske og estetiske fagene både i skole og lærerutdanning. Noen informanter uttrykker pessimisme over denne utviklingen, og andre uttrykker stor entusiasme over betydningen av akademisering for kompetanseutviklingen i eget fagfelt, med hovedfag og senere doktorgrader. Dette kan tyde på at informantene identifiserer seg mer med eget fagfelt enn med faggruppen. At det er så ulike syn på akademiseringsprosessene i egne fag kan både skyldes at de har forløpt ulikt, og at det ikke er enighet om hva som er ønsket utvikling.

\section{Faggruppens historisk-kulturelle konseptualisering}

De praktiske og estetiske fagene som faggruppe fremstår med et særpreg som «alltid har vært» og blir tatt for gitt (Koselleck, 1985). Imidlertid opptrer «praktiske fag» første gang i 1859 mens ordkombinasjoner av «praktisk» og «estetisk» opptrer første gang i 1924, og som flertallsbetegnelse for praktiskestetiske fag første gang i 1964 i det korpuset vi har undersøkt (jf. figur 2). Videre, som det fremgår av figur 2, har økningen av «estetiske fag» en tydelig topp fra 2000 - 2003. Det kan tenkes å være uttrykk for at estetiske fag ble diskutert mer, eventuelt ble gitt en bestemt status, eller ble oppfattet som særlig truet, i denne perioden da det var mange parallelle reforminitiativ i skole og lærerutdanning (jf. tidslinjen, figur 3). Kanskje kan en av informantenes spørsmål «hvem vil være et praktisk fag?» indikere at noen konseptualiseringer gjenspeiler asymmetrier mellom begrepsparet «praktisk» og «estetisk», der «praktiske fag» særlig forekom tidligere år, og «estetiske fag» særlig forekommer de senere år (jf. figur 2). Det kan være uttrykk for kamper om status og posisjoner, mellom vektlegging på fag man mener ivaretar den selvstendiggjorte estetiske erfaringen (Kittang, 1991) på den ene side og fagforståelser ut fra Dale (2008) sin argumentasjon om «praktiskestetiske fag» på den andre side. Om vi ser temporær tid i sammenheng med oppfattet tid, er det også mulig at asymmetriske historisk-kulturelle referanser som både er fortidige og nåtidige blir omplassert (Koselleck, 1985) i forbindelse med reformer (Olsen, 2007). Et eksempel på slike omplasseringer er hvordan det 
praktiske, håndverksmessige i kunst og håndverk, som en informant uttrykte bekymring for i forbindelse med L97, synes å bli oppgradert i dokumenter og debatter i forbindelse med Fagfornyelsen (Bråten \& Borgen, 2019). Den variasjonen i omtaler av faggruppen og enkeltfag vi har vist i dokumenter og debatter i forbindelse med Fagfornyelsen, kan slik sett være uttrykk for stadig pågående politikkutforming og endringer (jf. tidslinjen, figur 3) og forventninger til, og kamper om, mulige fremtidige omplasseringer.

\section{Politikkutforming og operasjonalisering av faggruppen}

Reformer gir rom for lokalt tolkningsmangfold og samspill som kan handle om definisjonsmakt, styring, posisjoner, kompetanse og om organisatorisk-historisk utvikling (Aderback \& Christensen, 2014). Ifølge Skinner (2002) og Koselleck (1985) handler konseptualisering om forståelser knyttet til tid og kontekst, og er alltid politisk. Gjennom sine tilnærminger får de frem «uordenen» i begrepers historie (Stråth, 2005). Vi har her vist hvordan denne uorden fremtrer i forbindelse med de praktiske og estetiske fagene i skole og lærerutdanning. Variasjonene i ordkombinasjoner i ulike dokumenter i det korpuset vi har undersøkt kan kanskje gjenspeile hvordan de formelle læreplaner og styringsdokumenter blir oppfattet ulikt, og oversatt og operasjonalisert ulikt (Goodlad, Klein \& Tye, 1979) både i skole og lærerutdanning. Selv om informantene knytter eksplisitte nøkkelhendelser til navneendring av enkeltfag i skolen, peker flere på mer implisitte og oversette sammenhenger med reformer i høyere utdanning og skole. Romantiske beskrivelser av de praktiske og estetiske fag som annerledes (Schou, 2005), og som praktiske og ikke-teoretiske (Molander, 1993) kan samtidig ha fungert retorisk i mer eller mindre eksplisitte forhandlinger om posisjoner, legitimering og makt (Bourdieu, 1988) mellom fagene så vel som for faggruppen. Som nevnt er dette også en kamp om ressurser i form av timer, økonomiske rammebetingelser og kompetanse som vi kan gjenkjenne i pågående debatter i dag.

Når reformer i skole og lærerutdanning over tid fremstår som sameksisterende, jf. tidslinjen, figur 3, og usynkroniserte (jf. Dahl m fl 2016), kan dette bidra til å vedlikeholde det som «alltid har vært» snarere enn å åpne opp for nye utviklingsinitiativ (jf. NOU 2015:8) og styrking av disse fagene i skolen (jf. St. meld nr. 28 (2015-16), s. 48). Dette kan kanskje forstås i lys av Koselleck (1985) som at aktører i fagene, ut fra erfaringer i fortid og nåtid, kan oppfatte ideer om fremtidige samfunnsbehov som muligheter for, eller som motarbeidelse av, noen bestemte egenskaper ved fagene, enkeltvis eller hele faggruppen.

\section{Avsluttende kommentar}

Vi har undersøkt historisk konseptualisering av faggruppen praktiske og estetiske fag i skole og lærerutdanning. I dokumenter, som er denne studiens kontekster, 
finner vi at enkelte ordkombinasjoner og enkeltord dominerer i noen perioder, og at noen av disse faller sammen i tid med mange nyere utdanningspolitiske reformer. Det er likevel variasjon som dominerer i omtalen av faggruppen, ved hjelp av ulike kombinasjoner av begrepene "praktisk» og «estetisk». Når det gjelder hva som legges i betydningen av ulike ordkombinasjoner og konseptualiseringens funksjon, har vi diskutert noen mulige betydninger, men vil være forsiktige med å lese for mye inn i variasjonene her. Det kan være gjort med hensikt, men behøver ikke være det. I tidslinjen har vi identifisert 29 styringsdokumenter for skole og lærerutdanning, men har innenfor rammen av denne artikkelen ikke gjort en nærmere analyse av dokumentene. Nøkkelhendelsene vi har identifisert, viser til både eksplisitte og mer implisitte og oversette sammenhenger, og bidrar til et rikere bilde av konseptualiseringer av faggruppen.

Gjennom å undersøke konseptualiseringer av faggruppen praktiske og estetiske fag over tid, i lys av det teoretiske rammeverket, har vi fått frem noen forhold ved faggruppen i skole og lærerutdanning, hvordan utdanningsreformer fungerer formativt, og bringer med seg historie og forventninger om mulig fremtid. Med denne studien ønsker vi å bidra forskningsmessig til fagutvikling for faggruppen. I lys av Goodlad sin læreplanøkologiske forståelse spør vi om det er bærekraftig at disse fagene i skole og lærerutdanning fungerer som separate, lukkede økosystemer i fremtiden, i et perspektiv på 20-30 år? Vi ser behov for mer forskning om forholdet mellom styringsdokumenter og operasjonaliseringer av fagene i skole og lærerutdanning fremover, og hvilke forutsetninger som ligger til grunn for at fagene kan ses i sammenheng som et fagområde i fremtidens skole, slik politikkutformingen i forbindelse med Fagfornyelsen etterspør.

\section{Om forfatterne}

Jorunn Spord Borgen er professor i de praktiske og estetiske fagenes pedagogikk ved Norges Idrettshøyskole og professor II ved Høgskulen på Vestlandet.

Institusjonstilknytning: Institutt for lærerutdanning og friluftslivsstudier, Norges idrettshøyskole/ Fakultet for lærarutdanning, kultur og idrett, Høgskulen på Vestlandet, 5020 Bergen.

E-post: jorunn.spord.borgen@nih.no 
Bjørg Oddrun Hallås er dosent i kroppsøving ved Høgskulen på Vestlandet. Institusjonstilknytning: Fakultet for lærarutdanning, kultur og idrett, Høgskulen på Vestlandet, 5020 Bergen.

E-post: bjorg.oddrun.hallas@hvl.no

Eli Heldaas Seland har PhD i kunsthistorie fra Universitetet i Bergen og arbeider som førstebibliotekar ved Høgskulen på Vestlandet.

Institusjonstilknytning: Høgskulen på Vestlandet, 5020 Bergen.

E-post: eli.heldaas.seland@hvl.no

Eli Kristin Aadland er førsteamanuensis i mat og helse ved Høgskulen på Vestlandet.

Institusjonstilknytning: Fakultet for lærarutdanning, kultur og idrett, Høgskulen på Vestlandet, 5020 Bergen.

E-post: eli.kristin.aadland@hvl.no

Njål Vindenes er professor emeritus i musikk ved Høgskulen på Vestlandet. Institusjonstilknytning: Fakultet for lærarutdanning, kultur og idrett, Høgskulen på Vestlandet, 5020 Bergen.

E-post: nvindenes@gmail.com

\section{Referanser}

Aadland, E. K., Borgen, J. S., Salvesen, G. S., Sæthre-McGuirk, E., Gjølme, E. G. \& Oftedal, K. H. (2017). Styrking av de praktiske og estetiske fagene i leererutdanningene. NRLU ad hoc-utvalg. Hentet fra https://www.uhr.no/_f/p1/if03b81a6-ddbb-47b3-9f752c0c7a7cd781/rapport-styrking-av-de-praktiske-og-estetiske-fagene-ilarerutdanningene.pdf

Aasen, P., Prøitz, T. \& Rye, E. (2015). Nasjonal læreplan som utdanningspolitisk dokument. Norsk Pedagogisk tidsskrift, 6(99), 417-433.

Aderback, J. D. \& Christensen, T. (2014). Why Reforms So Often Disappoint. American Review of Public Administration, 44(1) 3-16. https://doi.org/10.1177/0275074013504128

Augestad, P. (2003). Skolering av kroppen: om kunnskap og makt i kroppsøvingsfaget. Вø: Høgskolen i Telemark.

Bamford, A. (2006). The wow factor: Global research compendium on the impact of the arts in education. Münster: Waxmann Verlag

Baumgarten, A. G. (2008). Fra Aesthetica (1750). I K. Bale \& A. Bø-Rygg (Red.), Estetisk teori - en antologi (s. 11-16). Oslo: Universitetsforlaget.

Bindestrek. (2018). Bokmålsordboka. Universitetet i Bergen og Språkrådet. Hentet fra https://ordbok.uib.no/perl/ordbok.cgi?OPP=+bindestrek\&ant_bokmaal=5\&ant_nynorsk=5 \&begge $=+$ \&ordbok=begge

Blunden, A. (2012). Concepts. A Critical Approach. Studies in Critical Social Sciences. Leiden: Koninklijke Brill NV.

Boasson, F. \& Malvik, A. S. (2019). Digital humaniora, mediehistorie og litterære subjektivitetsuttrykk. Om forholdet mellom norsk litteratur og utviklingen av den 
kommersielle pressen 1855-1900 i et DH-perspektiv. Norsk litteraturvitenskapelig tidsskrift 2(22), 146-167.

Borgen, J. S. (1995). Formingsfaget i et oppdragelses-og dannelsesperspektiv. Formingsfagets egenart: en artikkel- og essaysamling. I. B. Thronshart (Red.), Formingsfagets egenart (s. 44-62). Notodden: Høgskolen i Telemark/Telemarksforskning.

Borgen, J. S (2011). The Cultural Rucksack in Norway: does the national model entail a programme for educational change? I J. Sefton- Green, P. Thomson, K. Jones \& L. Bresler (Red.), The Routledge International Handbook of Creative Learning. New York: Routledge.

Borgen, J. S (2017). From general transfer to deep learning as argument for practical aesthetic school subjects? Nordic Journal of Studies in Educational Policy, 3(3), 218-229. https://doi.org/10.1080/20020317.2017.1352439

Bourdieu, P. (1988). Homo Academicvs. California: Stanford University Press.

Bråten, I. og Borgen, J. S (2019). Hvor var det det butta, hvor er det blitt av alle gutta? FormAkademisk - Forskningstidsskrift for Design Og Designdidaktikk, 12(1). https://doi.org/10.7577/formakademisk.3239

By, I - A. (2015, 23. mars). Krafttak for praktiske og estetiske fag? Det er på høy tid å rette opp skjevheten som har utviklet seg mellom skolefagene. Blogginnlegg NIH. Hentet fra https://www.nih.no/om-nih/aktuelt/nih-bloggen/by-inger-ashild/pa-tide-med-et-krafttakfor-praktiske-og-estetiske-fag/

Dahl, T., Askling, B., Heggen, K., Kulbrandstad, L. I., Lauvdal, T., Qvortrup, L., (...) \& Mausethagen, S. (2016). Ekspertgruppa om lcererrollen: Om lcererrollen. Et kunnskapsgrunnlag. Bergen: Fagbokforlaget.

Dale, E. L. (1990). Kunnskapens tre og kunstens skjønnhet - om den estetiske oppdragelse i det moderne samfunn. Oslo: Gyldendal.

Dale, E. L. (2008) Fellesskolen - skolefaglig lcering for alle. Oslo: Cappelen Akademisk forlag.

Dale, E. L. (2010) Kunnskapsløftet. På vei mot felles kvalitetsansvar? Oslo: Universitetsforlaget.

Doll Jr, W. E. (1979). A structural view of curriculum. Theory Into Practice, 18(5), 336-348. https://doi.org/10.1080/00405847909542855

Eriksen, A. (2014, 26. november). Kunstfag for empati og respekt i skolen. Finnmark Dagblad. Hentet fra https://uit.no/Content/396833/Kunstfag\%20for\%20empati.pdf

Espeland, M., Allern, T-H., Carlsen, K. \& Kalsnes, S. (2011). Praktiske og estetiske fag og larerutdanning: En utredning fra en arbeidsgruppe nedsatt av Kunnskapsdepartementet høsten 2010, i samarbeid med høgskolene i Nesna, Telemark og Stord/Haugesund (HSHrapport 2011/1). Stord: Høgskolen Stord/Haugesund.

Espeland, M., Arnesen, T. E., Grønsdal, I. A., Holthe, A., Sømoe, K., Wergedahl, H. \& Aadland, H. (2013). Skolefagsundersøkelsen 2011. Praktiske og estetiske fag på barnesteget i norsk grunnskule (HSH-rapport 2013/7). Stord: Høgskolen Stord/Haugesund.

Goodlad, J. I. (1966). The development of a conceptual system for dealing with problems of curriculum and instruction. Los Angeles: University of California.

Goodlad, J. I., Klein, M. F. \& Tye, K. A. (1979). The domains of curriculum and their study. I Curriculum inquiry: The study of curriculum practice (s. 43-76). New York: McGrawHill Book Company.

Gundem, B. B. (1990). Læreplanpraksis og læreplanteori: En introduksjon til lcereplanområdet. Oslo: Universitetsforlaget.

Hellevik, O. (1994). Forskningsmetode i sosiologi og statsvitenskap. Oslo: Universitetsforlaget 
Hermansen, H., Lorentzen, M., Mausethagen, S. \& Zlatanovic, T. (2018). Hva kjennetegner forskning på lærerrollen under Kunnskapsløftet? En forskningskartlegging av studier av norske lærere, lærerstudenter og lærerutdannere. Acta Didactica Norge, 12(1), 1-36. http://dx.doi.org/10.5617/adno.4351

Hetland, L. \& Winner, E. (2004). Cognitive Transfer From Arts Education to Nonarts Outcomes: Research Evidence and Policy Implications. I E. W. Eisner \& M. D. Day (Red.), Handbook of Research and Policy in Art Education. National Art Education Association. New Jersey: Lawrence Erlbaum Associates.

Holdhus, K. \& Christoffersen, C. (2019, 7. mars). Du trenger ikke vente på læreplanen, Sanner! Dagsavisen. Hentet fra https://www.dagsavisen.no/nyemeninger/du-trenger-ikkevente-p\%C3\%A5-1\%C3\%A6replanen-sanner-1.1290096

Jelstad, J. (2019, 7. februar). Prioriter bedre lærere i praktiske fag - ikke mattekarakteren. Utdanningsnytt. Hentet fra https://www.utdanningsnytt.no/nyheter/2019/februar/kritisketil-forslag-om-at-matte-skal-telle-mer/

Jensen, I. L. F. (2008). Mat og helse, mestring og dannelse. I P. Arneberg \& L. G. Briseid (Red.), Fag og danning: mellom individ og fellesskap (s. 175-192 ). Bergen: Fagbokforlaget.

Jørgensen, D. (2018). The Intermediate World: A Key Concept in Beautiful Thinking. Open Philosophy, 1(1), 50-58, https://doi.org/10.1515/opphil-2018-0005

Kittang, A. (1991). Estetikk og poetikk: Supplerande kommentarar. I: K. Gundersen \& S. Wikshåland (Red.), EST I: grunnlagsproblemer i estetisk forskning (s. 71-80). Oslo: Norges allmennvitenskapelig forskningsråd.

Kirke- og undervisningsdepartementet. (1973). Lov av 8.juni 1973 nr 49 om lærarutdanning. Oslo: Grøndahl.

Kirke-, utdannings- og forskningskomiteen. 2016. Innstilling fra Kirke-, utdannings- og forskningskomiteen om Fag - Fordypning - Forståelse, En fornyelse av Kunnskapsløftet Meld. St. 28 (2015-2016) (Innst. 19 S (2016-2017).

Koselleck, R. (1985). Futures Past: On the Semantics of Historical Time. New York: Columbia University Press.

Kunnskapsdepartement. (2009.) Læreren, rollen og utdanningen (Meld. St.11 (2008-2009)). Hentet fra https://www.regjeringen.no/no/dokumenter/stmeld-nr-11-2008-2009/id544920/

Kunnskapsdepartementet (2016). St meld nr 28 (2015-16) Fag - Fordypning - Forståelse. En fornyelse av Kunnskapsløftet. Hentet fra: https://www.regjeringen.no/no/dokumenter/meld.-st.-28-20152016/id2483955/sec1

Kunnskapsdepartementet (2019). Rammeplaner for høyere utdanning. Hentet fra: https://www.regjeringen.no/no/tema/utdanning/hoyere-utdanning/rammeplaner/id435163/

Kvale, S. \& Brinkmann, S. (2010). Det kvalitative forskningsintervju. Gyldendal Akademisk.Lindgren, M. \& Ericsson, C. (2013) Diskursiva legitimeringar av estetisk verksamhet i lärarutbildningen. I L. Bergman, I. Ericsson, L. Lang, C. Ljungberg, M. Lundström \& T. Småberg (Red.), Educare. Vetenskapliga skrifter (s. 7-40). Malmö: Holmbergs AS

Lorentzen, S. (2017, 10. september). Da norsk skole åpnet seg mot verden. Bergens Tidende. Hentet fra https://www.bt.no/btmeninger/kronikk/i/Gdx8m/da-norsk-skole-aapnet-segmot-verden

Molander, B. (1993). Kunskap i handling. Gøteborg: Daidalos.

Nasjonalbiblioteket. (2015). NB N-gram. http://www.nb.no/sp_tjenester/beta/ngram_1/

Naul, R. (2011). Conceptual diversity and future directions of physical education in the global context. Japanese Journal of Sport Education Studies, 30(2), 39-50.

https://doi.org/10.7219/jjses.30.2_39 
Og. (2018). Bokmålsordboka. Universitetet i Bergen og Språkrådet. Hentet fra https://ordbok.uib.no/perl/ordbok.cgi?OPP=+og\&ant_bokmaal=5\&ant_nynorsk=5\&begge $=+$ \&ordbok=begge

Olsen, J. (2007). The Institutional Dynamics of the European University. I P. Maassen \& J. Olsen (Red.), University Dynamics and European Integration. Higher Education Dynamics (s. 25-54). Dordrecht: Springer.

Palonen, K. (2002). The History of Concepts as a Style of Political Theorizing: Quentin Skinner's and Reinhart Koselleck's Subversion of Normative Political Theory. European Journal of Political Theory, 1 (1), 91-106. https://doi.org/10.1177/1474885102001001007

Popkewitz, T. S. (2009). Curriculum study, curriculum history, and curriculum theory: the reason of reason. Journal of Curriculum Studies, 41(3), 301-319. https://doi.org/10.1080/00220270902777021

Rian, H. O. (2019). Hvordan skal du styrke de praktisk-estetiske fagene, Sanner? Utdanningsnytt.no, 08.03.2019. Hentet fra: https://www.utdanningsnytt.no/debatt/2019/februar/hvordan-skal-du-styrke-de-praktiskestetiske-fagene-sanner/

Schou, L. R. (2005). Undervisningens æstetiske dimension. Nordic Studies in Education, 1 (25), 44-53.

Skinner, Q. (2002). Visions of Politics: Regarding Method Volume 1. Cambridge: Cambridge University Press. https://doi.org/10.1017/CBO9780511790812

Sollid, H. (2013). Intervju som forskningsmetode i klasseromsforskning. I M. Brekke \& T: Tiller (2013). Læreren som forsker. Innføring i forskningsarbeid i skolen (s. 124-138). Oslo: Universitetsforlaget

Steinsholt, K. (1997). Refleksjon og ettertanke. Trondheim: Tapir Forlag.

Stråth, B. (2005). Review essay. European Journal of Social Theory 8(4), 527-532. https://doi.org/10.1177/1368431005056742

Taylor, J.R., Flanagin, A. J., Cheney, G. \& Seibold, D. R. (2001). Organizational Communication Research: Key Moments, Central Concerns, and Future Challenges. Annals of the International Communication Association, 24 (1), 99-137. https://doi.org/10.1080/23808985.2001.11678983

Telhaug, A.O., Mediås, O.A. \& Aasen, P (2006). The Nordic Model in Education: Education as part of the political system in the last 50 years. Scandinavian Journal of Educational Research, 50(3), 245-283. https://doi.org/10.1080/00313830600743274

Thorgersen, K. \& Alerby, E. (2005). One word to rule them? The word aesthetics in curricula for the Swedish compulsory school of today. Utbildning och Demokrati, 14(1), 63-79.

Varkøy, Ø. (2006). Hvorfor musikk? - en musikkpedagogisk idéhistorie. Oslo: Gyldendal Akademisk.

Vindenes, N. (2008). Notar i praksis: Fernando Sor. Op.35, No. 4. I A. Nyrnes \& N. Lehmann (Red.), Ut frå det konkrete. Bidrag til ein retorisk kunstfagdidaktikk (s. 67-87). Oslo: Universitetsforlaget.

Winner, E., Goldstein, T. R. \& Vincent-Lancrin, S. (2013). Art for art's sake? The impact of arts education (s. 21 - 56). Centre for Educational Research and Innovation CERI: OECD Publishing. https://dx.doi.org/10.1787/9789264180789-en

Wittgenstein, L. (1969/1992). Om Visshet. Stockholm: Bokförlaget Thales.

Østerud, P., Sunnanå, S. \& Frøysnes, Å. (2015). Norsk lcerarutdanning i etterkrigstida. Ei utvikling i spenning mellom tradisjon og fornying. Oslo: ABM-media as. 


\section{Appendix 1}

\section{St. meld om grunnskole:}

Utdannings- og forskningsdepartementet. (2003). «Et blot til lyst». Om kunst og kultur i og i tilknytning til grunnskolen (St. meld. nr. 39 (2002-2003)). Hentet fra https://www.regjeringen.no/no/dokumenter/stmeld-nr-39-2002-2003-/id197064/

Utdannings- og forskningsdepartementet. (2004). Kultur for læring (St. meld. nr. 30 (20032004)). Hentet fra https://www.regjeringen.no/no/dokumenter/stmeld-nr-030-2003-2004$\underline{\text { id404433/ }}$

Kunnskapsdepartementet. (2016). Fag - Fordypning - Forståelse. En fornyelse av Kunnskapsløftet (Meld. St. 28 (2015-2016)). Hentet fra https://www.regjeringen.no/no/dokumenter/meld.-st.-28-20152016/id2483955/

\section{Læreplan grunnskole:}

Forsøksrådet for skoleverket. (1960). Lœreplan for forsøk med 9-årig skole. Forsøk og reform i skolen - nr. 5. Aschehoug. Hentet fra https://www.nb.no/nbsok/nb/78a7b5fbbb8f0f471bceae2667c53111?lang=no\#7

Kirke- og undervisningsdepartementet. (1970). Forslag til ny normalplan for grunnskolen. Aschehoug. Hentet fra https://www.nb.no/items/URN:NBN:nonb_digibok_2011011806046?page $=3$

Kirke- og undervisningsdepartementet. (1974). Mønsterplan for grunnskolen. Aschehoug. Hentet fra https://www.nb.no/items/URN:NBN:no-nb_digibok_2008052804017?page=1

Kirke- og undervisningsdepartementet. (1987). Mønsterplan for grunnskolen. Aschehoug. Hentet fra https://www.nb.no/items/URN:NBN:no-nb_digibok_2007080200101?page=0

Kirke-, utdannings- og forskningsdepartement (1997) Lcreplanverket for den 10-årige grunnskolen. Nasjonalt læremiddelsenter. Hentet fra https://www.nb.no/items/URN:NBN:nonb_digibok_2008080100096?page $=351$

Kunnskapsdepartementet. (2006). Lœreplanverket for Kunnskapsløftet. Utdanningsdirektoratet. Hentet fra https://www.udir.no/laring-og-trivsel/lareplanverket/hvordan-er-lareplanene-bygd-opp/

\section{St. meld om lærerutdanning:}

Kyrkje- og undervisningsdepartementet. (1964). Om læererutdanning (St. meld. nr. 69 (196364)). Hentet fra https://www.nb.no/items/URN:NBN:no-nb_digibok_2013010908026

Utdannings- og forskningsdepartementet. (1990). Lærerutdanning ved høgskoler og universitet (St. meld. nr. 53 (1989-90)).

Kyrkje-, utdannings- og forskingsdepartementet. (1997). Om læererutdanning (St. meld. nr. 48 (1996-97)). Hentet fra https://www.nb.no/nbsok/nb/bd706035c95b42bd1200a4859bfa7bfb.nbdigital?lang=no\#5 
Utdannings- og forskingsdepartementet. (1999). ...og yrke skal båten bera... Handlingsplan for rekruttering til leraryrke (St. meld. nr. 12 (1999-2000)). Hentet fra https://www.regjeringen.no/no/dokumenter/stmeld-nr-12-1999-2000-/id431667/

Kunnskapsdepartementet. (2009). Læreren. Rolla og utdanningen (St. meld. nr. 11 (20082009)). Hentet fra https://www.regjeringen.no/no/dokumenter/stmeld-nr-11-2008-2009id544920/

Planer for lærerutdanning:

Kyrkje- og undervisningsdepartementet. (1965). Undervisningsplan for den 2-årige og 4årige lcererskolen. Hentet fra https://www.nb.no/items/URN:NBN:no$\underline{\text { nb_digibok_2007042601039 }}$

NOU 1974: 58. (1974). Lerarutdanning. Oslo: Kyrkje- og undervisningsdepartementet

Kyrkje- og undervisningsdepartementet. (1980). Studieplan for allmennlæererutdanning. Universitetsforlaget. Hentet fra https://www.nb.no/items/URN:NBN:no-nb_digibok_2007062800027?page=3

Lærarutdaningsrådet. (1986). Studieplan for allmennlærarutdaning. Hentet fra: https://www.nb.no/items/URN:NBN:no-nb_digibok_2009070301140?page=0

Kyrkje-, utdannings- og forkningsdepartementet. (1994). Rammeplan for 4-årig Allmennlæererutdanning. Oslo: Lærerutdanningsrådet. Hentet fra https://www.nb.no/nbsok/nb/9d8af012957154a463d558720afd4436?lang=no\#0

Kyrkje-, utdannings- og forskningsdepartementet. (1999). Rammeplan for 4-årig Allmennlærerutdanning. Hentet fra https://www.regjeringen.no/globalassets/upload/kilde/ufd/pla/2003/0001/ddd/pdfv/175022allmennlaererutdanning.pdf

Utdannings- og forskningsdepartementet. (2003). Rammeplan for Allmennlcererutdanningen. Hentet fra:

https://www.regjeringen.no/globalassets/upload/kilde/kd/pla/2006/0002/ddd/pdfv/175666rammeplan_2003_allmennlaererutd.pdf

Kunnskapsdepartementet. (2010a). Nasjonale retningslinjer for grunnskolelærerutdanningen 1.-7.og 5.-10. trinn. Hentet fra https://www.regjeringen.no/no/dokumenter/nasjonaleretningslinjer-for-grunnskolel/id640249/

Nasjonalt råd for lærerutdanning. (2016a). Nasjonale retningslinjer for grunnskolelcererutdanning trinn 1.-7. Hentet fra https://www.uhr.no/_f/p1/ibda59a76-750c43f2-b95aa7690820ccf4/revidert-171018-nasjonale-retningslinjer-forgrunnskolelarerutdanningtrinn-1-7_fin.pdf

Nasjonalt råd for lærerutdanning. (2016b). Nasjonale retningslinjer for grunnskolelcrerutdanning trinn 5.-10. Hentet fra https://www.uhr.no/_f/p1/iffeaf9b9-678645f5-8f31- e384b45195e4/revidert-171018-nasjonale-retningslinjer-for-grunnskoleutdanningtrinn-5-10_fin.pdf 


\section{St. meld om høyere utdanning:}

Kultur- og vitenskapsdepartementet. (1985). Om høyere utdanning (St. meld nr. 66 (198485)). Hentet fra https://www.stortinget.no/no/Saker-og-

publikasjoner/Stortingsforhandlinger/Lesevisning/?p=1984-

$\underline{\text { 85\&paid=3\&wid=e\&psid=DIVL70\&pgid=e_0141 }}$

Kultur- og vitenskapsdepartementet. (1989). Om forsking (St. meld. nr. 28 (1988-89)). Hentet fra https://www.nb.no/items/URN:NBN:no-nb_digibok_2012081508232?page=5

Kyrkje, utdannings- og forskningsdepartementet. (1991). Fra visjon til virke. Om høgre utdanning (St. meld. nr. 40 (1990-91)). Hentet fra https://www.nb.no/items/URN:NBN:nonb_digibok_2009091800010?page $=5$

Utdannings- og forskningsdepartementet. (2001). Gjør din plikt - Krev din rett. Kvalitetsreform av høyere utdanning. (St. meld. nr. 27 (2000-2001)). Hentet fra https://www.regjeringen.no/no/dokumenter/stmeld-nr-27-2000-2001-/id194247/sec1

Utdannings- og forskningsdepartementet. (2002). Kvalitetsreformen. Om ny lærerutdanning. Mangfoldig - krevende - relevant (St. meld. nr.16 (2001-2002)). Hentet fra https://www.regjeringen.no/no/dokumenter/stmeld-nr-16-2001-2002-/id195517/ 